\title{
Loading and Light Degradation Characteristics of Bt Toxin on Nanogoethite: A Potential Material for Controlling the Environmental Risk of Bt Toxin
}

\author{
Xueyong Zhou, ${ }^{1}$ Chongmei She, ${ }^{1,2}$ and Huifen Liu ${ }^{2}$ \\ ${ }^{1}$ Tianjin Engineering and Technology Research Center of Agricultural Products Processing, \\ College of Food Science and Bioengineering, Tianjin Agricultural University, Tianjin 300384, China \\ ${ }^{2}$ College of Agronomy and Resources Environment, Tianjin Agricultural University, Tianjin 300384, China
}

Correspondence should be addressed to Xueyong Zhou; zhouxueyongts@163.com

Received 7 September 2015; Revised 23 November 2015; Accepted 24 November 2015

Academic Editor: Yijun Shi

Copyright (C) 2015 Xueyong Zhou et al. This is an open access article distributed under the Creative Commons Attribution License, which permits unrestricted use, distribution, and reproduction in any medium, provided the original work is properly cited.

\begin{abstract}
Transgenic Bt-modified crops release toxins into soil through root exudates and upon decomposition of residues. The fate of these toxins in soil has not been yet clearly elucidated. Nanogoethite was found to have a different influence on the lifetime and insecticidal activity of Bt toxin. The aim of this study was to elucidate the adsorption characteristics of Bt toxin on nanogoethite and its activity changes before and after adsorption. The adsorption of toxin on nanogoethite reached equilibrium within $5 \mathrm{~h}$, and the adsorption isotherm of Bt toxin on nanogoethite conformed to the Langmuir equation $\left(R^{2}>0.9690\right)$. In the range of $\mathrm{pH}$ from 6.0 to 8.0 , larger adsorption occurred at lower $\mathrm{pH}$ value. The toxin adsorption decreased with the temperature between 10 and $50^{\circ} \mathrm{C}$. The results of FTIR, XRD, and SEM indicated that toxin did not influence the structure of nanogoethite and the adsorption of toxin only on the surface of nanogoethite. The $\mathrm{LC}_{50}$ value for bound toxin was higher than that of free toxin, and the nanogoethite greatly accelerated the degradation of toxin by ultraviolet irradiation. The above results suggested that nanogoethite is a potential material for controlling the environmental risk of toxin released by Bt transgenic plants.
\end{abstract}

\section{Introduction}

Bacillus thuringiensis is a bacterium present in various environments, especially in the soil. During sporulation, $B$. thuringiensis produces crystals composed of proteins toxic to insects and other organisms, and the proteins produced by different strains of the bacterium are toxic to different species of insects, including various pests. Thus, the genes that encode these toxic proteins are important in agriculture, as the genes introduced into crop plants can render the plants resistant to its pests, thereby decreasing the need for chemical insecticides [1]. Genetically modified (GM) crops were first commercialized in 1996 and their use has rapidly expanded. A 105-fold increase of globally grown biotech crops has been reported from 1.7 million hectares in 1996 to 181.5 million hectares in 2014 [2]. However, there is a concern that genetically engineered crops may pose risks to natural and agricultural ecosystems $[3,4]$. When genes that code for the production of these toxins are genetically engineered into plants, the toxins may continue to be synthesized and to be released into the soil in the growing period of plants [5]. In the case of transgenic plants, only usable portions of the plants are harvested, and the remainder of the plants' biomass containing the toxin is incorporated into the soil. Hence, the concentration of toxin in soil will be larger and present for longer periods than that introduced with commercial preparations of $B$. thuringiensis [6]. If production exceeds consumption by insect larvae and degradation by the soil microbiota, the toxin could accumulate to concentrations that may (1) constitute a hazard to nontarget organisms and (2) result in the selection and enrichment of toxin-resistant target insects [7]. The persistence of insecticidal protein is a function primarily of (1) the concentration added; (2) the rate of consumption by insect larvae; (3) the rate of inactivity and degradation by the indigenous microbiota and sunlight [8]. The toxins produced by transgenic plants were 
adsorbed rapidly (in $<30 \mathrm{~min}$, the shortest time studied) on mined clay minerals (montmorillonite and kaolinite), the clay-size fraction of soil, humic acids extracted from soil, and complexes of clay and humic acids $[9,10]$. The insecticidal activity of bound toxin was comparable with or higher than that of free toxin $[6,11]$. The adsorbed toxin is less accessible to microbial degradation, and its insecticidal activity can persist for $180 \mathrm{~d}$ or $234 \mathrm{~d}$ [8].

It is important to study the environmental risk of toxin from Bt transgenic plants and the methods for overcoming the risk. Goethite, $\alpha$-FeOOH, is one of the most widespread forms of iron oxides in terrestrial soils, sediments, and ore deposits, as well as a common weathering product in rocks of all types [12, 13]. We found that some characteristics of nanogoethite were different with general soil minerals; for example, the persistent period of the toxin adsorbed on nanogoethite was far shorter than that of free toxin, which was inconsistent with the previous studies. Therefore, nanogoethite may be a potential material for control of the environmental risk of toxin in the soil. To our knowledge, no related studies have been published. The objectives of this study are to (1) investigate the loading capacity of nanogoethite for Bt toxin and (2) understand the effect of nanogoethite on the light degradation of Bt toxin.

\section{Material and Methods}

2.1. Purification of Toxin. The transgenic insecticidal CrylAb protein (toxin) was expressed by an engineered strain (Escherichia coli), which was provided by the State Key Laboratory of Huazhong Agricultural University. The engineered strain producing CrylAb insecticidal crystal protein (ICP) was cultivated in a fermentor, at $30^{\circ} \mathrm{C}$ for $40 \mathrm{~h}$ with constant aeration until sporulation. The Bt powder was obtained by spray drying.

The complexes of crystals and spores were washed three times with $1 \mathrm{~mol} / \mathrm{L} \mathrm{NaCl}$ and three times with thrice distilled water. The toxin was purified from the crystals and spores using Huber buffer $\left(0.1 \mathrm{~mol} / \mathrm{L} \quad \mathrm{Na}_{2} \mathrm{CO}_{3}-\mathrm{HCl}\right.$, containing $25 \mathrm{mmol} / \mathrm{L}$ dithiothreitol, $\mathrm{pH}$ 9.5) [14]. The supernatant was sequentially filtered through $0.8,0.45$, and $0.2 \mu \mathrm{m}$ filters and dialyzed against distilled water for $48 \mathrm{~h}$. The CrylAb protein precipitate was centrifuged at 20,000 g and then lyophilized. The molecular weight of the toxin was $66 \mathrm{kDa}$ and consisted of 618 amino acid residues.

2.2. Preparation of Nanogoethite. Nanogoethite was prepared by dissolving $50 \mathrm{~g} \mathrm{Fe}\left(\mathrm{NO}_{3}\right)_{3} \cdot 9 \mathrm{H}_{2} \mathrm{O}$ in $825 \mathrm{~mL}$ deionized water and titrated with $25 \mathrm{~mol} / \mathrm{L} \mathrm{NaOH}$ at the rate of $5 \mathrm{~mL} / \mathrm{min}$ until the $\mathrm{pH}$ was near 12 . The suspension was sonicated at $60^{\circ} \mathrm{C}$ for $48 \mathrm{~h}$ and then left standing for $10 \mathrm{~h}$. The supernatant was removed and the precipitate was washed three times with deionized water and centrifuged at $8000 \mathrm{~g}$ for $15 \mathrm{~min}$. The precipitate was resuspended in deionized water and the $<200 \mathrm{~nm}$ particles were separated by centrifugation. The sample was identified by the XRD analysis. The specific surface area was $152.3 \mathrm{~m}^{2} / \mathrm{g}\left(\mathrm{N}_{2}\right.$ adsorption method using the ST-2000/ST08A instrument, Beijing Analytical Instrument Company);
IEP (isoelectric point) was 8.2 (Zeta potential method using Shanghai Zhongchen Digital Technic Apparatus Company, China. The Zeta potential was plotted versus $\mathrm{pH}$ value, and the IEP was obtained according to the intersection point between the curve and horizontal coordinate).

2.3. Adsorption Experiment. Two hundred milligrams of lyophilized toxin from $B$. thuringiensis was dissolved in $100 \mathrm{~mL}$ of $0.05 \mathrm{~mol} / \mathrm{L}$ sodium phosphate buffer ( $\mathrm{pH} \mathrm{6-8).}$ The insoluble material was discarded after centrifugation at $20,000 \mathrm{~g}$ for $20 \mathrm{~min}$. The concentration of toxin was determined by ultraviolet spectrometry at $280 \mathrm{~nm}$ using bovine serum albumin (BSA) as standard. Nanogoethite was suspended in sterilized deionized water at a concentration of $8 \mathrm{mg} / \mathrm{mL}$. The adsorption was investigated at different time intervals from 0.5 to $7 \mathrm{~h}$. The adsorption isotherm was measured in the range of toxin concentrations from 0.25 to $1.0 \mathrm{mg} / \mathrm{mL}$ and nanogoethite concentration of $0.25 \mathrm{mg} / \mathrm{mL}$ at $\mathrm{pH}$ 8.0. The nanogoethite-toxin mixtures were shaken at $25 \pm 1^{\circ} \mathrm{C}$ for $5 \mathrm{~h}$. The suspension was centrifuged at $20,000 \mathrm{~g}$ for $20 \mathrm{~min}$ and the absorbance of supernatant was measured as indicated previously. The amount of toxin adsorbed and percent adsorption were calculated according to (1). The control experiment was performed with nanogoethite in the absence of toxin

$$
Q=\frac{V\left(C_{0}-C_{1}\right)}{W},
$$

where $Q$ is the adsorption amount, $\mathrm{mg} / \mathrm{mg} ; C_{0}$ is the concentration of toxin before adsorption, $\mathrm{mg} / \mathrm{mL} ; C_{1}$ is the concentration of toxin after equilibrium adsorption, $\mathrm{mg} / \mathrm{mL}$; $V$ is the volume of adsorption solution, $\mathrm{mL} ; W$ is the weight of nanogoethite, mg.

The percent adsorption $A_{p}(\%)$ can be calculated by

$$
A_{p}=\frac{C_{0}-C_{1}}{C_{0}} \times 100 .
$$

Effect of the nanogoethite concentration on adsorption was measured in the range of mineral concentrations from 0.25 to $1.0 \mathrm{mg} / \mathrm{mL}$ and a toxin concentration of $0.5 \mathrm{mg} / \mathrm{mL}$ at $\mathrm{pH}$ 8.0. Effect of $\mathrm{pH}$ on adsorption was conducted in the range of $\mathrm{pH}$ from 6.0 to 8.0 (phosphate buffer) at a toxin concentration of $0.15 \mathrm{mg} / \mathrm{mL}$ and a nanogoethite concentration of $0.5 \mathrm{mg} / \mathrm{mL}$. Effect of temperature on adsorption was investigated from 10 to $50^{\circ} \mathrm{C}$ with a toxin concentration of $0.5 \mathrm{mg} / \mathrm{mL}$ and a nanogoethite concentration of $1.0 \mathrm{mg} / \mathrm{mL}$ at $\mathrm{pH}$ of 8.0. For all the experiment three repeats were performed and standard deviation was calculated.

2.4. Determination of Insecticidal Activity. The toxin adsorbed on nanogoethite was diluted to $100 \mu \mathrm{g} / \mathrm{mL}$. Twenty milliliters of the diluted solution was transferred into a Petri dish (diameter $10 \mathrm{~cm}$ ), which was placed under a 20 -watt ultraviolet lamp emitting a wave length of $253.7 \mathrm{~nm}$. The vertical distance between the lamp and the Petri dish was $30 \mathrm{~cm}$. The Petri dish was shaken for $10 \mathrm{~s}$ every $15 \mathrm{~min}$. After one hour of irradiation, the insecticidal activity of the toxin adsorbed on nanogoethite was determined. 


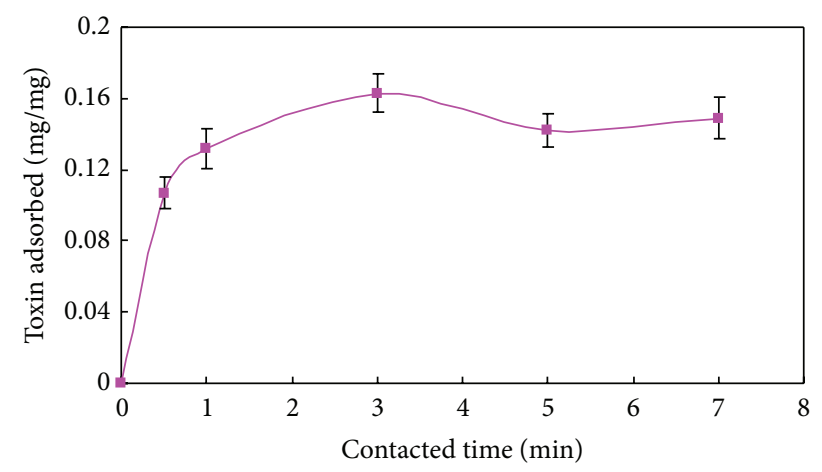

FIGURE 1: Effect of contacted time on the adsorption amount of $\mathrm{Bt}$ toxin on nanogoethite. The initial concentration of $\mathrm{Bt}$ toxin was $0.5 \mathrm{mg} / \mathrm{mL}$; nanogoethite concentration $1.0 \mathrm{mg} / \mathrm{mL}, \mathrm{pH} 8.0$, and temperature $25 \pm 1^{\circ} \mathrm{C}$.

Heliothis armigera was used to determine the insecticidal activity of toxin. To prepare the infection feed, the free toxin and equivalent amount of toxin bound on nanogoethite were diluted to $100,50,25,12.5,6.25$, and $3.13 \mu \mathrm{g} / \mathrm{mL}$. Twenty milliliters of liquid feed was dispersed into 24 holes of an incubation plate. After air-drying, one instar larva was placed into each hole and incubated at $30 \pm 2^{\circ} \mathrm{C}$ for $72 \mathrm{~h}$. The lethality was determined and the lethal concentration to kill $50 \%$ of the larvae $\left(\mathrm{LC}_{50}\right)$ was calculated. Sterilized nanogoethite instead of Bt toxin sample was used as control.

2.5. X-Ray Diffraction (XRD). Relative changes in the basal spacing of nanogoethite before and after CrylAb protein adsorption were identified by X-ray diffraction (XRD). The oriented samples on glass slides were scanned by a diffractometer (Rigaku D/max-2500, Japan). The diffraction angle $(2 \theta)$ was from $3^{\circ}$ to $80^{\circ}$ with a scanning speed of $8^{\circ} / \mathrm{min}$. $\mathrm{Cu} \mathrm{k} \alpha$ radiation was used as the $\mathrm{X}$-ray source, which was operated at $40 \mathrm{kV}$ and $100 \mathrm{~mA}$, respectively.

\subsection{Infrared Spectroscopy and Scanning Electron Microscope.} Fourier transform infrared (FTIR) adsorption spectra of CrylAb protein, nanogoethite before and after immobilization of CrylAb protein were recorded on a Nicolet AVATAR 330 spectrometer using $\mathrm{KBr}$ pellets. For each sample, a total of 64 scans at $4 \mathrm{~cm}^{-1}$ resolution were used. The surface morphology of nanogoethite before and after immobilization of CrylAb protein was examined on a Hitachi S-4800 scanning electron microscope (equipped with an $\mathrm{X}$-ray dispersive analyzer).

\section{Results and Discussion}

3.1. Effect of Time. The adsorption of toxin on nanogoethite increased rapidly initially and then reached equilibrium within $5 \mathrm{~h}$ (Figure 1). No remarkable increase in adsorption was observed after $5 \mathrm{~h}$. Therefore, the adsorption time for $5 \mathrm{~h}$ was chosen in other experiments. Previous study showed that the adsorption of toxin on mined clay minerals (montmorillonite and kaolinite), the clay-size fraction of soil, reached

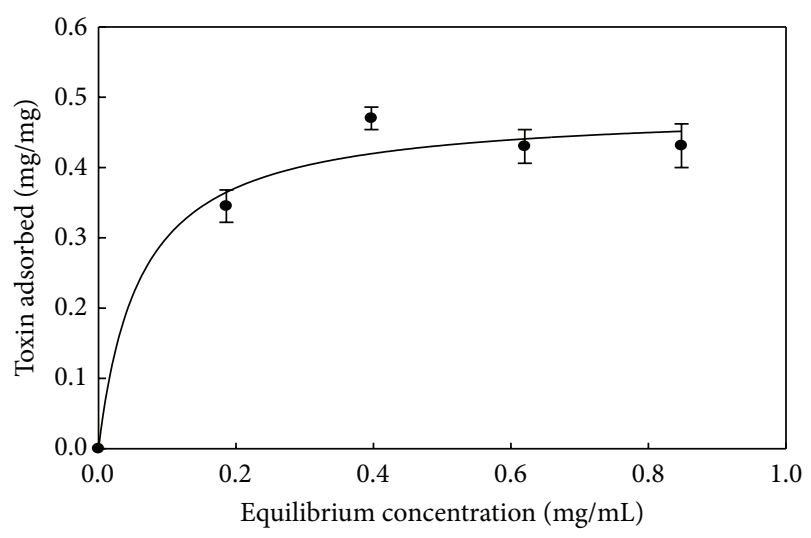

FIGURE 2: Isotherm of adsorption of $\mathrm{Bt}$ toxin on nanogoethite. The initial concentration of Bt toxin ranged from 0.25 to $1.0 \mathrm{mg} / \mathrm{mL}$, the concentration of nanogoethite was $0.25 \mathrm{mg} / \mathrm{mL}, \mathrm{pH}$ was 8.0 , and temperature was $25 \pm 1^{\circ} \mathrm{C}$.

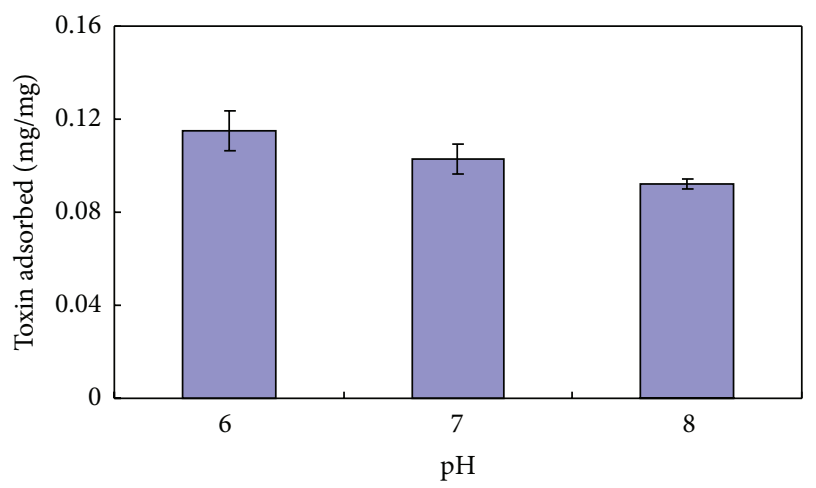

Figure 3: Effect of $\mathrm{pH}$ on the adsorption amount of Bt toxin on goethite. The initial concentration of Bt toxin and nanogoethite was $0.15 \mathrm{mg} / \mathrm{mL}$ and $0.5 \mathrm{mg} / \mathrm{mL}$, respectively, and temperature was $25 \pm 1^{\circ} \mathrm{C}$.

equilibrium within $30 \mathrm{~min}$ [7]. The present study indicated that the adsorption time of $\mathrm{Bt}$ toxin varied with the types of minerals.

3.2. Adsorption Isotherms. The adsorption data were fitted to the Langmuir equation with high regression coefficient $\left(R^{2}>0.9690\right)$. In the range of toxin concentrations from 0.25 to $1.0 \mathrm{mg} / \mathrm{mL}$, the adsorption amounts increased rapidly at the initial stage and then reached equilibrium gradually (Figure 2). The maximal adsorption amount of $\mathrm{Bt}$ toxin calculated by the Langmuir equation was $0.48 \mathrm{mg} / \mathrm{mg}$.

3.3. Effect of $p H$. In phosphate buffer, the amount of toxin adsorbed on nanogoethite decreased by $20.0 \%$ from $\mathrm{pH} 6.0$ to 8.0 (Figure 3).

Adsorption of protein on mineral may involve a variety of physical and chemical interactions such as electrostatic force, hydrogen bond, hydrophobic force, and Van der Waals force $[9,15]$. Protein molecules encounter minimal repulsive forces with each other at the IEP (isoelectric point), which results in maximum collisions with charged mineral surfaces. 
TABLE 1: Insecticidal activity of the free toxin, goethite-toxin complexes, and powder of B. thuringiensis before and after ultraviolet irradiation.

\begin{tabular}{|c|c|c|c|}
\hline \multirow{3}{*}{ Sample ${ }^{a}$} & \multicolumn{3}{|c|}{$\mathrm{LC}_{50}^{\mathrm{b}}$} \\
\hline & Before ultraviolet irradiation & After ultraviolet irradiation & Change $^{c}$ \\
\hline & & $\mu \mathrm{g} / \mathrm{mL}$ & $\%$ \\
\hline Free toxin & $10.00 \pm 2.37$ & $13.1 \pm 3.02$ & 31.0 \\
\hline Goethite-toxin & $695.29 \pm 70.31$ & $6840.61 \pm 840.35$ & 883.8 \\
\hline Powder of $B$. thuringiensis & $28.4 \pm 3.40$ & $36.2 \pm 6.05$ & 27.5 \\
\hline
\end{tabular}

${ }^{a}$ There were no mortalities with the mineral alone.

${ }^{\mathrm{b}}$ Lethal concentration to kill $50 \%$ of the larvae.

${ }^{\mathrm{c}} \mathrm{Change}=\left[\left(\mathrm{LC}_{50}\right.\right.$ after ultraviolet irradiation $-\mathrm{LC}_{50}$ before ultraviolet irradiation $) / \mathrm{LC}_{50}$ before ultraviolet irradiation $] \times 100$.

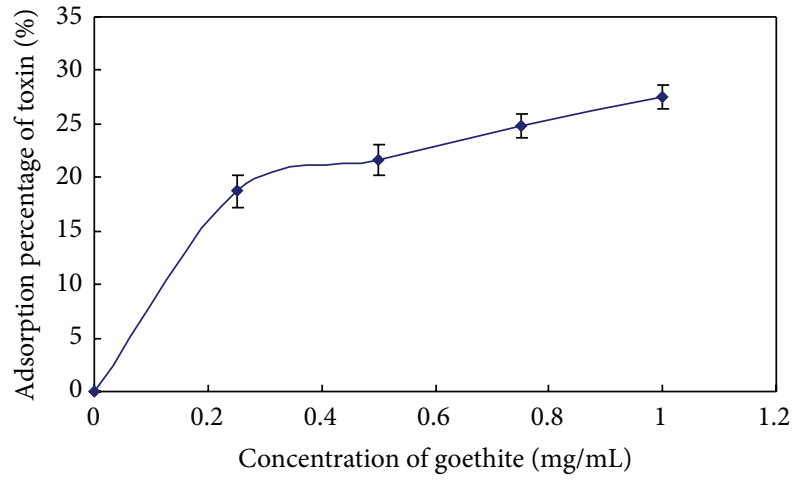

FIGURE 4: Effect of concentration of nanogoethite on the adsorption percentage of $\mathrm{Bt}$ toxin. The initial concentration of Bt toxin was $0.5 \mathrm{mg} / \mathrm{mL}$, the concentration of nanogoethite ranged from 0.25 to $1.0 \mathrm{mg} / \mathrm{mL}$, $\mathrm{pH}$ was 8.0 , and temperature was $25 \pm 1^{\circ} \mathrm{C}$.

Greater adsorption at lower $\mathrm{pH}$ observed in our experiment was attributed to the IEP (5.5) of toxin from B. thuringiensis, which was consistent with the recent studies $[16,17]$.

3.4. Effect of Nanogoethite/Toxin Ratio. At a fixed toxin concentration $(0.50 \mathrm{mg} / \mathrm{mL})$, the adsorption percentage of toxin increased with nanogoethite concentration from 0.25 to $1.0 \mathrm{mg} / \mathrm{mL}$ until a more or less flat plateau was attained (Figure 4). However, when the data were expressed as the amount of toxin adsorbed per unit weight of nanogoethite, the relative toxin adsorption decreased as the amount of the nanogoethite was decreased (Figure 5). When the nanogoethite concentrations were 0.25 and $1.00 \mathrm{mg} / \mathrm{mL}$, the amount of the toxin adsorbed on the nanogoethite was 0.29 and $0.11 \mathrm{mg} / \mathrm{mg}$, respectively.

3.5. Effect of Temperature. As temperature increased from 10 to $50^{\circ} \mathrm{C}$ the amount of toxin adsorbed on nanogoethite decreased by $8.4 \%$ (Figure 6). Venkateswerlu and Stotzky [18] reported that the adsorption of protoxin and toxin on montmorillonite and kaolinite was not considerably affected by temperature between 7 and $50^{\circ} \mathrm{C}$. Zhou et al. [19] found that the adsorption of protoxin and toxin on montmorillonite, kaolinite, and silica was a spontaneous, exothermic process in the range of temperature from 278 to $318 \mathrm{~K}$, which was consistent with the present studies.

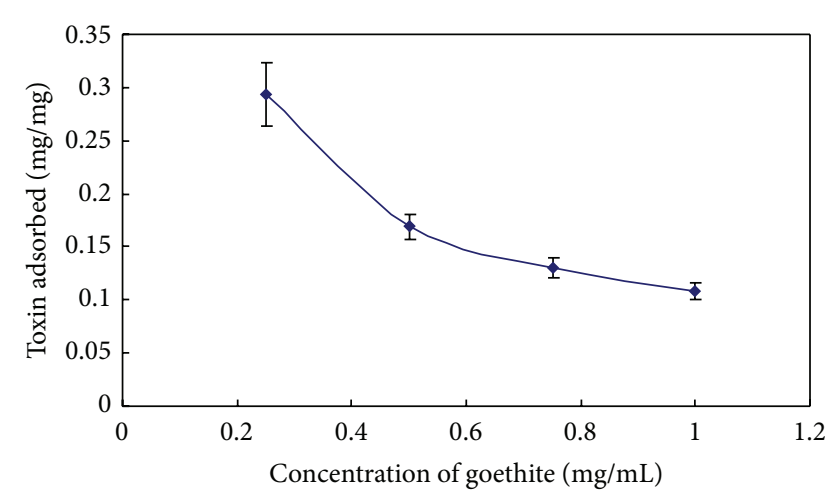

FIGURE 5: Effect of concentration of nanogoethite on the adsorption amount of Bt toxin. The initial concentration of Bt toxin was $0.5 \mathrm{mg} / \mathrm{mL}$, the concentration of nanogoethite ranged from 0.25 to $1.0 \mathrm{mg} / \mathrm{mL}$, $\mathrm{pH}$ was 8.0 , and temperature was $25 \pm 1^{\circ} \mathrm{C}$.

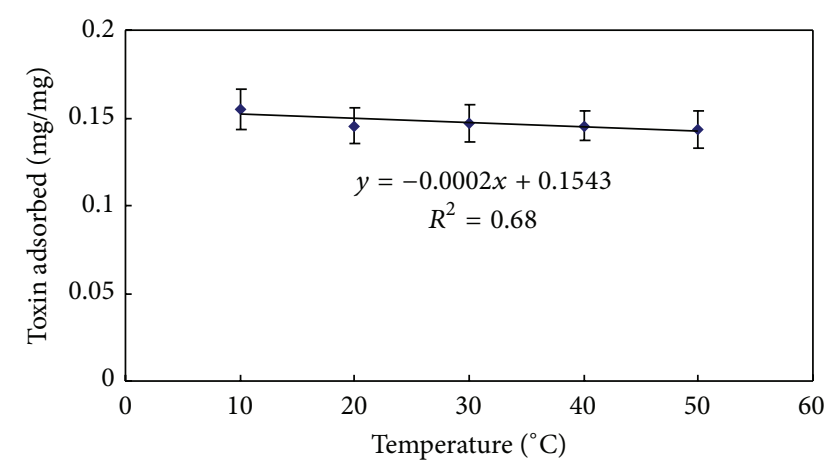

FIGURE 6: Effect of temperature on the adsorption amount of Bt toxin onto nanogoethite. The initial concentration of Bt toxin was $0.5 \mathrm{mg} / \mathrm{mL}$; nanogoethite concentration was $1.0 \mathrm{mg} / \mathrm{mL}$, pH 8.0.

3.6. The Insecticidal Activity of Nanogoethite-Toxin Complexes. As shown in Table 1, both free and bound toxin were toxic to the larvae of Heliothis armigera. The $\mathrm{LC}_{50}$ values for bound toxin were higher than that of free toxin; that is, the insecticidal activity of toxin decreased after adsorption on nanogoethite, which was inconsistent with the previous study [20]. In fact, the insecticidal activity and degradation depend on the types of toxin and minerals, $\mathrm{pH}$, temperature, and other physicochemical and biological characteristics of soil $[4,21]$. 
After one hour of ultraviolet irradiation, the $\mathrm{LC}_{50}$ of the free toxin and the $B$. thuringiensis powder increased by $31.0 \%$ and $27.5 \%$, respectively, whereas the adsorbed toxin on nanogoethite increased by $883.8 \%$. Zhou et al. [22] reported that montmorillonite and rectorite could protect the protoxin from ultraviolet irradiation damage, but zinc oxide and kaolinite accelerated the damage of ultraviolet irradiation. Nevertheless, the accelerated extent for the degradation of toxin by nanogoethite was much higher than those by zinc oxide and kaolinite. The reasons for the fast degradation of toxin bound on nanogoethite can be attributed to two aspects:

(1) The nanogoethite $(\alpha-\mathrm{FeOOH})$ is a mineral with a high IEP (8.2), which is much higher than the common soils. The soil $\mathrm{pH}$ has important influence on the degradation and persistence of Cry proteins. For example, the proteins appear to persist longer in acidic soil, as a result of decreased microbial activity at the lower $\mathrm{pH}[21,23]$. Therefore, the stability of toxin in alkaline or neutral condition was less than that in acidic condition.

(2) The nanogoethite has a function of catalytic decomposition for organic matter [24,25]. Therefore, the fast degradation of toxin adsorbed by nanogoethite may be due to its catalytic characteristics.

3.7. XRD Analysis of Nanogoethite-Toxin Complexes. The basal spacing of nanogoethite before and after CrylAb protein adsorption was shown in Figure 7. There was no expansion of the basal spacing when compared with the pure mineral alone, as the goethite is not layered mineral. The intensity of peaks, however, slightly decreased $[26,27]$. The toxin extracted by alkaline solution is not crystal but amorphous powder; its adsorption results in a decrease of diffraction intensity of nanogoethite crystal. The XRD result showed that the adsorption and binding of CrylAb protein apparently occurred only on the external surface of mineral.

3.8. FTIR Spectra of Nanogoethite-Toxin Complexes. As shown in Figure 8, the three bands in native CrylAb toxin are centered at 1534,1234 , and $1029 \mathrm{~cm}^{-1}$, respectively. The $1534 \mathrm{~cm}^{-1}$ components are assigned to $\mathrm{C}-\mathrm{N}$ stretching of the amide II groups of the toxin; the band at $1234 \mathrm{~cm}^{-1}$ is attributed to $\mathrm{C}-\mathrm{N}$ stretching as well as $\mathrm{N}-\mathrm{H}$ bending vibration in the amide III group, and the $1029 \mathrm{~cm}^{-1}$ band is C-O or C-N stretching. The 3402 and $2926 \mathrm{~cm}^{-1}$ bands are attributed to N$\mathrm{H}$ stretching of the amide $\mathrm{A}$ and $\mathrm{C}-\mathrm{H}$ stretching of methylene groups, respectively. The $1641 \mathrm{~cm}^{-1}$ band of the protein amide I is similar to the stretching vibration of water; therefore, it is not used to analyze the FTIR spectra.

The main absorption bands of nanogoethite are at $800 \mathrm{~cm}^{-1}(\delta-\mathrm{OH})$ and $897 \mathrm{~cm}^{-1}$ (hydroxyl bending vibration on $\mathrm{Fe}-\mathrm{OH}-\mathrm{Fe}$ ) [28] and $1000 \mathrm{~cm}^{-1}$ and $3100 \mathrm{~cm}^{-1}$, of free hydroxyl for bending vibration on $\mathrm{Fe}-\mathrm{OH}$. After the adsorption of CrylAb toxin, the amide $\mathrm{A}$ and methylene bands of the complexes occur at 3404 and $2922 \mathrm{~cm}^{-1}$, respectively, and wavenumber shifts of $2-4 \mathrm{~cm}^{-1}$ were observed.
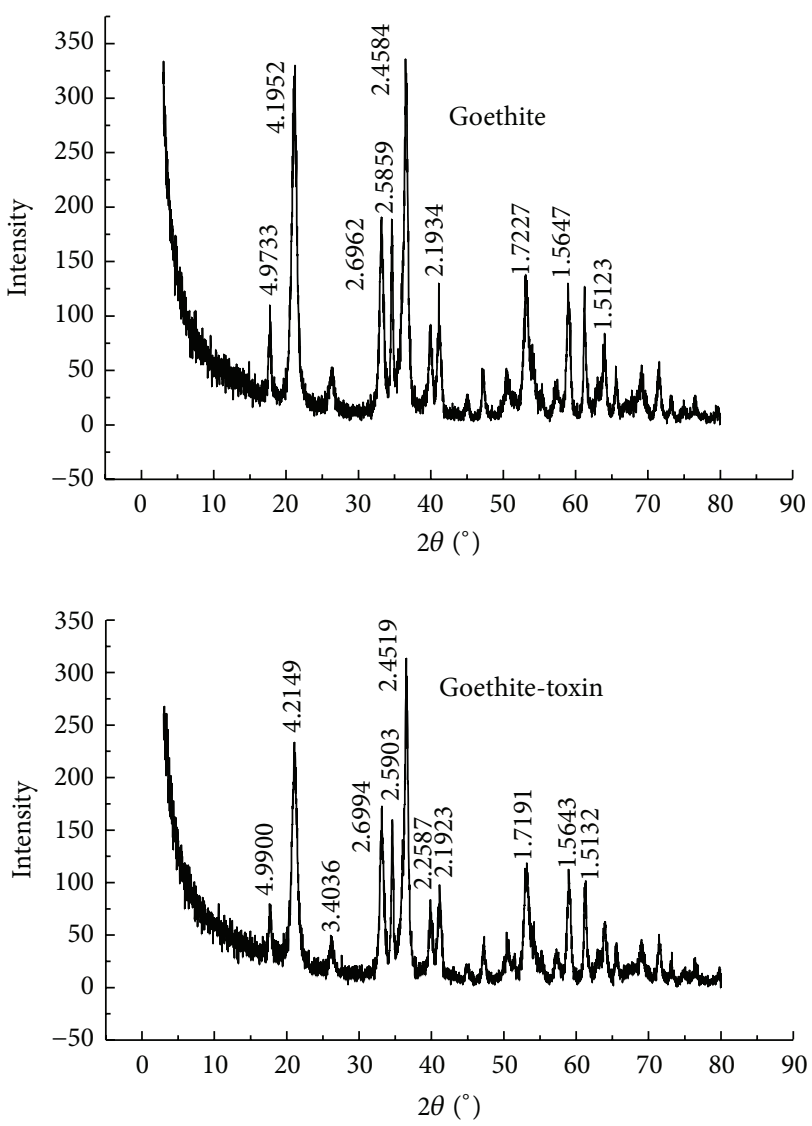

FIGURE 7: XRD patterns of the goethite and goethite-toxin.

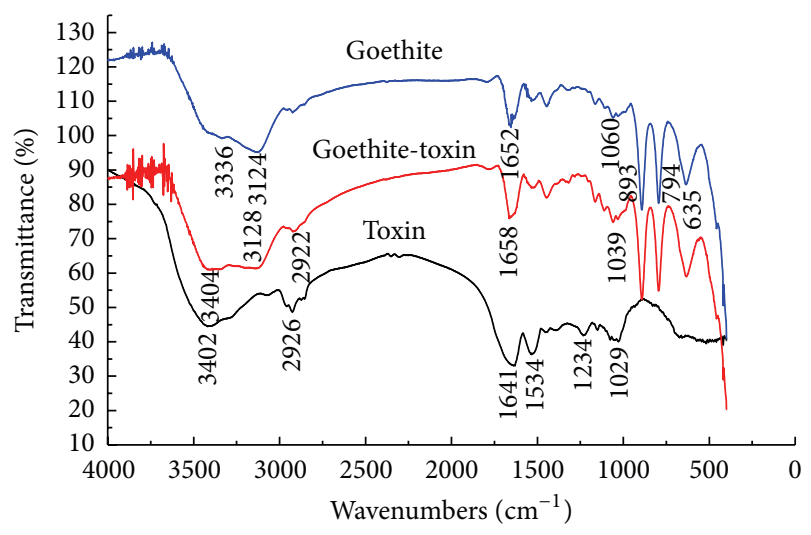

FIGURE 8: FTIR spectra of toxin before and after adsorption by nanogoethite.

The absorption band of CrylAb toxin at $1029 \mathrm{~cm}^{-1}$ shifted to $1039 \mathrm{~cm}^{-1}$.

3.9. SEM Analysis of Nanogoethite-Toxin Complexes. Morphology of nanogoethite (Figure 9(a)) and nanogoethite-Bt toxin (Figure 9(b)) was observed on a scanning electron microscope (SEM, Hitachi S-4800). Before the adsorption of toxin, nanogoethite is in the state of aggregation of needlelike crystal. After the adsorption of toxin, the aggregation 


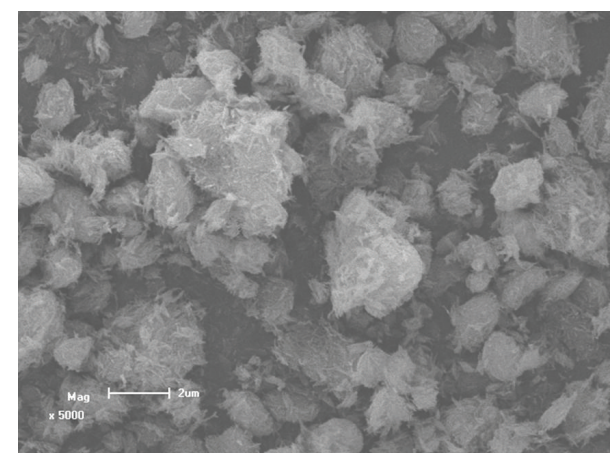

$\left(a_{1}\right)$

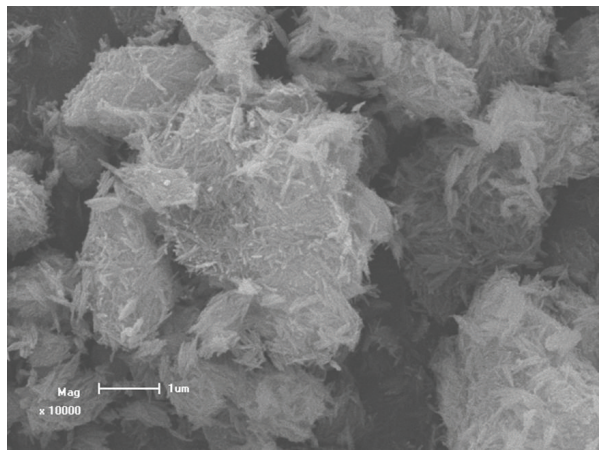

$\left(a_{2}\right)$

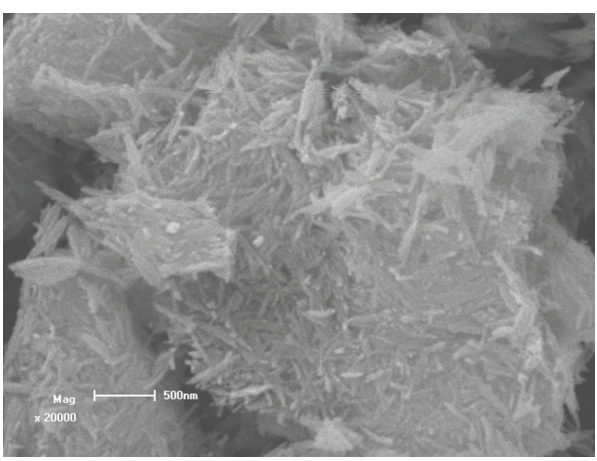

$\left(a_{3}\right)$

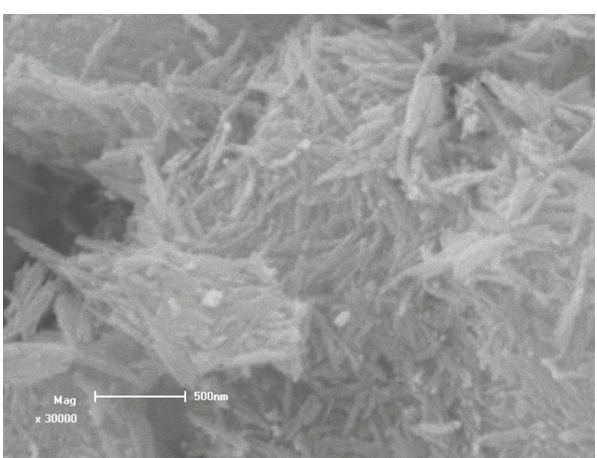

$\left(\mathrm{a}_{4}\right)$

(a)

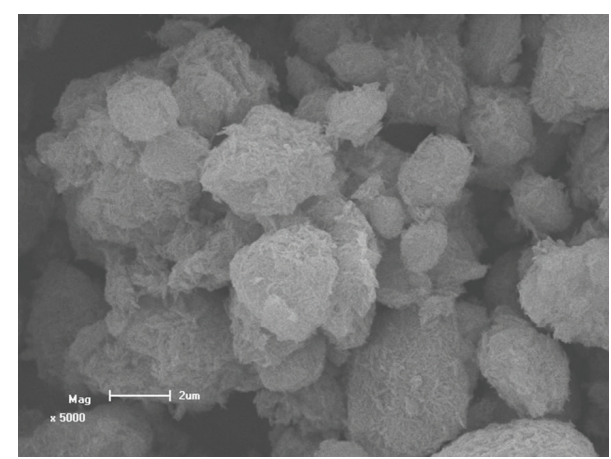

$\left(b_{1}\right)$

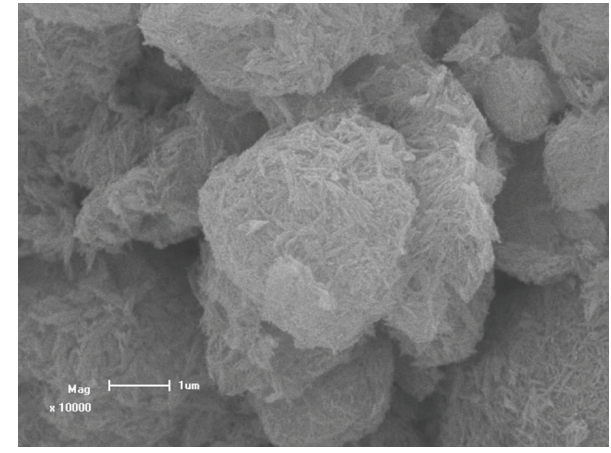

$\left(b_{2}\right)$

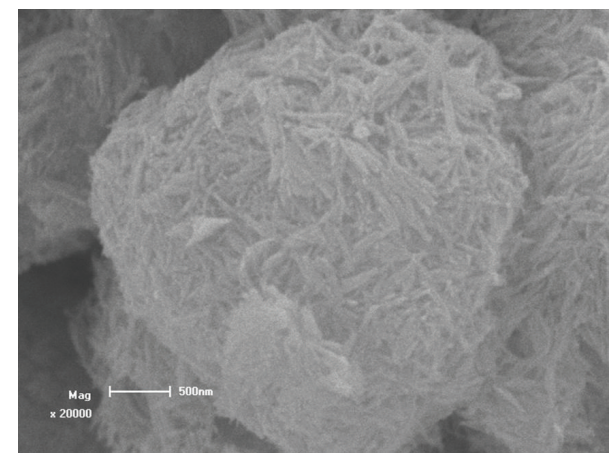

$\left(b_{3}\right)$

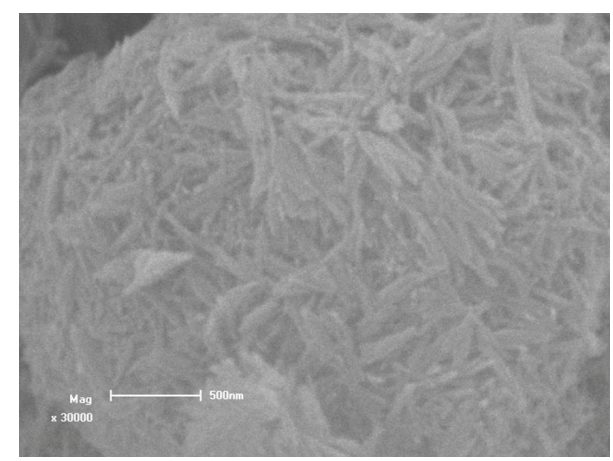

$\left(b_{4}\right)$

(b)

FIGURE 9: SEM micrographs of goethite (a) and goethite-Bt toxin $(b) .\left(a_{1}\right),\left(a_{2}\right),\left(a_{3}\right)$, and $\left(a_{4}\right)$ mean that the magnification for goethite is $5000 x, 10000 x, 20000 x$, and 30000x, respectively; $\left(b_{1}\right),\left(b_{2}\right),\left(b_{3}\right)$, and $\left(b_{4}\right)$ mean that the magnification for goethite-toxin complexes is $5000 x$, 10000x, 20000x, and 30000x, respectively. 
degree of nanogoethite increased; this may be due to the package action of macromolecular protein to mineral particles.

\section{Conclusions}

After much study, this report investigated the adsorption and light degradation characteristics of Bt toxin on nanogoethite. The adsorption isotherm of toxin on nanogoethite conformed to the Langmuir equation $\left(R^{2}>0.9690\right)$, and the maximal adsorption amount was $0.48 \mathrm{mg} / \mathrm{mg}$. In the range of $\mathrm{pH}$ from 6.0 to 8.0 , larger adsorption occurred at $\mathrm{pH}$ 6.0. With the increase of the nanogoethite/toxin ratio, the amount of adsorption $(\mathrm{mg} / \mathrm{mg}$ ) decreased but the adsorption percentage (\%) increased. The adsorption of toxin on nanogoethite reached equilibrium within $5 \mathrm{~h}$. The toxin adsorption decreases with the temperature between 10 and $50^{\circ} \mathrm{C}$. The results of FTIR, XRD, and SEM indicated that toxin did not influence the structure of nanogoethite. The $\mathrm{LC}_{50}$ value for bound toxin was higher than that of free toxin; that is, the insecticidal activity of toxin decreased after adsorption by nanogoethite. The nanogoethite accelerated greatly the degradation of toxin by ultraviolet irradiation. The above results suggested that nanogoethite is probably a potential material for controlling the environmental risk of toxin released from transgenic plants.

\section{Conflict of Interests}

The authors declare that there is no conflict of interests regarding the publication of this paper.

\section{Acknowledgments}

The authors' thanks first go to the institutions from which the funding is available. The research was funded by the National Natural Science Foundation of China (no. 31470573 and no. 31070478).

\section{References}

[1] I. Icoz and G. Stotzky, "Cry3Bbl protein from Bacillus thuringiensis in root exudates and biomass of transgenic corn does not persist in soil," Transgenic Research, vol. 17, no. 4, pp. 609-620, 2008.

[2] C. James, Global Status of Commercialized Biotech/GM Crops: 2014, 2014, http://www.isaaa.org/resources/publications/pocketk/16/.

[3] N. Helassa, G. Daudin, S. Noinville et al., "Mobility of adsorbed CrylAa insecticidal toxin from Bacillus thuringiensis (Bt) on montmorillonite measured by fluorescence recovery after photobleaching (FRAP)," Philosophical Magazine, vol. 90, no. 17-18, pp. 2365-2371, 2010.

[4] K. E. Strain and M. J. Lydy, "The fate and transport of the CrylAb protein in an agricultural field and laboratory aquatic microcosms," Chemosphere, vol. 132, pp. 94-100, 2015.

[5] D. Saxena, S. Flores, and G. Stotzky, "Bt toxin is released in root exudates from 12 transgenic corn hybrids representing three transformation events," Soil Biology and Biochemistry, vol. 34, no. 1, pp. 133-137, 2002.

[6] C. Crecchio and G. Stotzky, "Insecticidal activity and biodegradation of the toxin from Bacillus thuringiensis subsp. Kurstaki bound to humic acids from soil," Soil Biology and Biochemistry, vol. 30, no. 4, pp. 463-470, 1998.

[7] D. Saxena, C. N. Stewart, I. Altosaar, Q. Shu, and G. Stotzky, "Larvicidal Cry proteins from Bacillus thuringiensis are released in root exudates of transgenic $B$. thuringiensis corn, potato, and rice but not of $B$. thuringiensis canola, cotton, and tobacco," Plant Physiology and Biochemistry, vol. 42, no. 5, pp. 383-387, 2004.

[8] G. Stotzky, "Persistence and biological activity in soil of insecticidal proteins from Bacillus thuringiensis and bacterial DNA bound on clays and humic acids," Journal of Environmental Quality, vol. 29, no. 3, pp. 691-705, 2000.

[9] N. Helassa, H. Quiquampoix, S. Noinville, W. Szponarski, and S. Staunton, "Adsorption and desorption of monomeric Bt (Bacillus thuringiensis) CrylAa toxin on montmorillonite and kaolinite," Soil Biology and Biochemistry, vol. 41, no. 3, pp. 498504, 2009.

[10] H. Wang, Q. Ye, J. Gan, and J. Wu, "Adsorption of CrylAb protein isolated from Bt transgenic rice on bentone, kaolin, humic acids, and soils," Journal of Agricultural and Food Chemistry, vol. 56, no. 12, pp. 4659-4664, 2008.

[11] X. Zhou, Q. Huang, S. Chen, and Z. Yu, "Adsorption of the insecticidal protein of Bacillus thuringiensis on montmorillonite, kaolinite, silica, goethite and Red soil," Applied Clay Science, vol. 30, no. 2, pp. 87-93, 2005.

[12] Í. G. Gonçalves, C. O. Petter, and J. L. Machado, "Quantification of hematite and goethite concentrations in kaolin using diffuse reflectance spectroscopy: a new approach to Kubelka-Munk theory," Clays and Clay Minerals, vol. 60, no. 5, pp. 473-483, 2012.

[13] H. Yang, R. Lu, R. T. Downs, and G. Costin, "Goethite, $\alpha$ $\mathrm{FeO}(\mathrm{OH})$, from single-crystal data," Acta Crystallographica Section E, vol. 62, no. 12, pp. i250-i252, 2006.

[14] Z. Yu, Bacillus thuringiensis, Science Press, Beijing, China, 1990.

[15] Q. Fu, Y. Dong, H. Hu, and Q. Huang, "Adsorption of the insecticidal protein of Bacillus thuringiensis subsp. kurstaki by soil minerals: effects of organic acid ligands," Applied Clay Science, vol. 37, no. 1-2, pp. 201-206, 2007.

[16] N. Helassa, A. M'Charek, H. Quiquampoix et al., "Effects of physicochemical interactions and microbial activity on the persistence of CrylAa Bt (Bacillus thuringiensis) toxin in soil," Soil Biology and Biochemistry, vol. 43, no. 5, pp. 1089-1097, 2011.

[17] M. Sander, M. Madliger, and R. P. Schwarzenbach, "Adsorption of transgenic insecticidal CrylAb protein to $\mathrm{SiO}_{2}$. 1. Forces driving adsorption," Environmental Science and Technology, vol. 44, no. 23, pp. 8870-8876, 2010.

[18] G. Venkateswerlu and G. Stotzky, "Binding of the protoxin and toxin proteins of Bacillus thuringiensis subsp. kurstaki on clay minerals," Current Microbiology, vol. 25, no. 4, pp. 225-233, 1992.

[19] X. Zhou, N. Liu, J. Gao, M. Zhang, and F. Cao, "Adsorption thermodynamics of toxin $(65 \mathrm{kDa})$ and protoxin $(130 \mathrm{kDa})$ from Bacillus thuringiensis by several minerals," International Journal of Chemical Reactor Engineering, vol. 9, article A5, 2011. 
[20] C. Crecchio and G. Stotzky, "Biodegradation and insecticidal activity of the toxin from Bacillus thuringiensis subsp. kurstaki bound on complexes of montmorillonite-humic acidsAl hydroxypolymers," Soil Biology and Biochemistry, vol. 33, no. 4-5, pp. 573-581, 2001.

[21] I. Icoz and G. Stotzky, "Fate and effects of insect-resistant Bt crops in soil ecosystems," Soil Biology and Biochemistry, vol. 40, no. 3, pp. 559-586, 2008.

[22] X. Zhou, J. Gao, S. Chen, and B. Wang, "Adsorption and antiultraviolet light characteristics of the protoxin from Bacillus thuringiensis on montmorillonite, kaolinite, zinc oxide and rectorite," Biocontrol Science and Technology, vol. 18, no. 10, pp. 1051-1061, 2008.

[23] H. Tapp and G. Stotzky, "Persistence of the insecticidal toxin from Bacillus thuringiensis subsp. Kurstaki in soil," Soil Biology and Biochemistry, vol. 30, no. 4, pp. 471-476, 1998.

[24] L. M. Chun, "Oxidation of chlorophenols with hydrogen peroxide in the presence of nano-goethite," Chemosphere, vol. 40, pp. 125-130, 2000.

[25] S. Chou, C. Huang, and Y.-H. Huang, "Heterogeneous and homogeneous catalytic oxidation by supported $\gamma$ - $\mathrm{FeOOH}$ in a fluidized-bed reactor: kinetic approach," Environmental Science and Technology, vol. 35, no. 6, pp. 1247-1251, 2001.

[26] Guiyang Institute of Geochemistry of Chinese Academy of Sciences, Identify Manual of Mineral X-Ray Power Pattern, Science Press, Beijing, China, 1978 (Chinese).

[27] N. Kaur, M. Gräfe, B. Singh, and B. Kennedy, "Simultaneous incorporation of $\mathrm{Cr}, \mathrm{Zn}, \mathrm{Cd}$, and $\mathrm{Pb}$ in the goethite structure," Clays and Clay Minerals, vol. 57, no. 2, pp. 234-250, 2009.

[28] L. A. Pérez-Maqueda, J. Šubrt, V. Balek, J. M. Criado, and C. Real, "Use of emanation thermal analysis in characterisation of nanosized hematite prepared by dry grinding of goethite," Journal of Thermal Analysis and Calorimetry, vol. 60, no. 3, pp. 997-1007, 2000. 

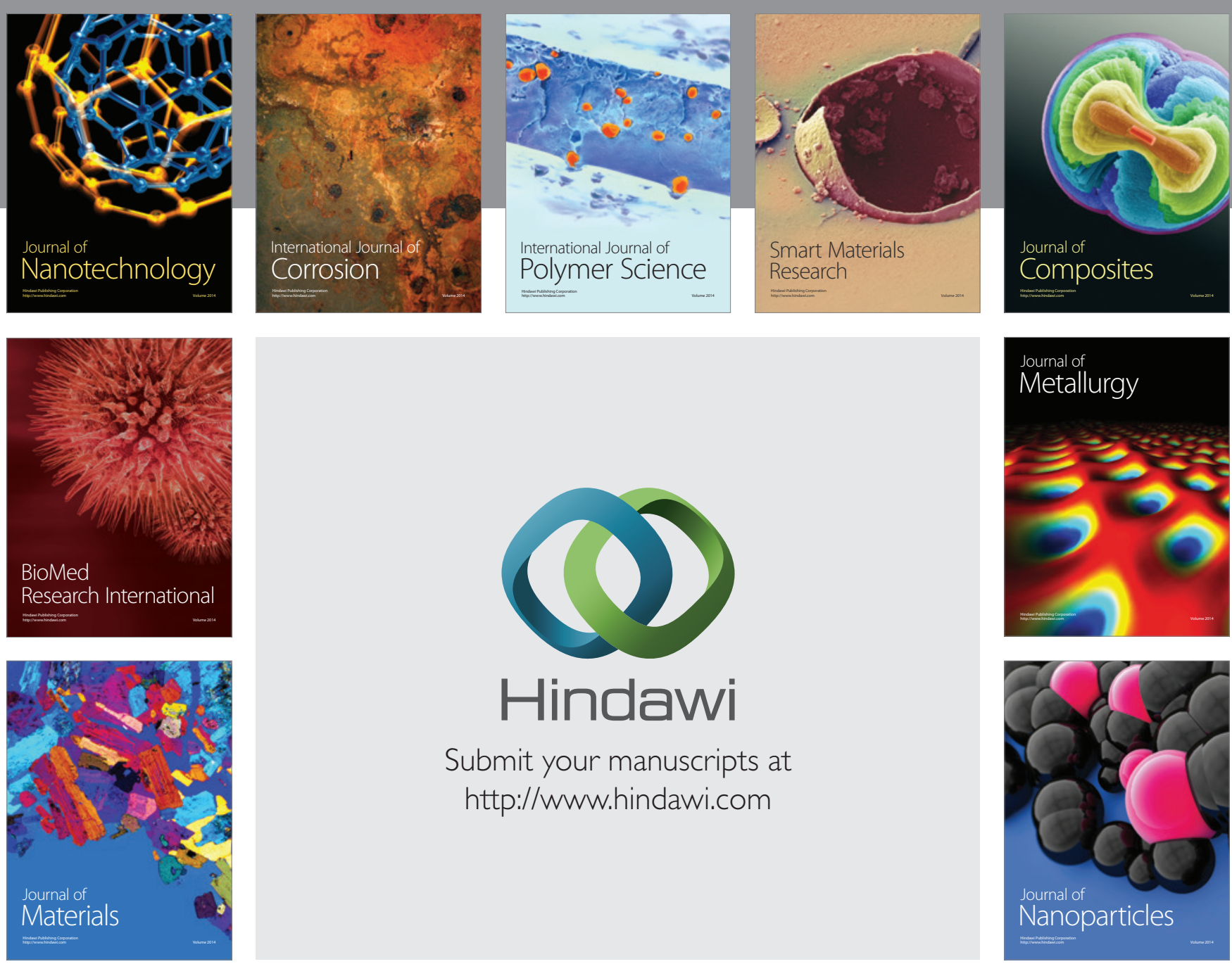

Submit your manuscripts at http://www.hindawi.com
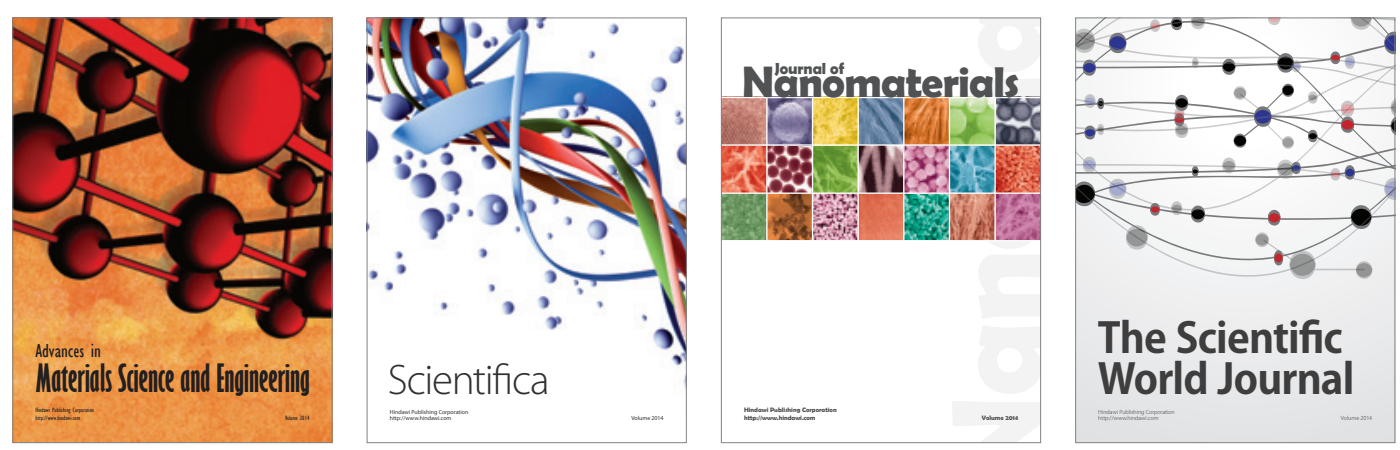

\section{The Scientific World Journal}
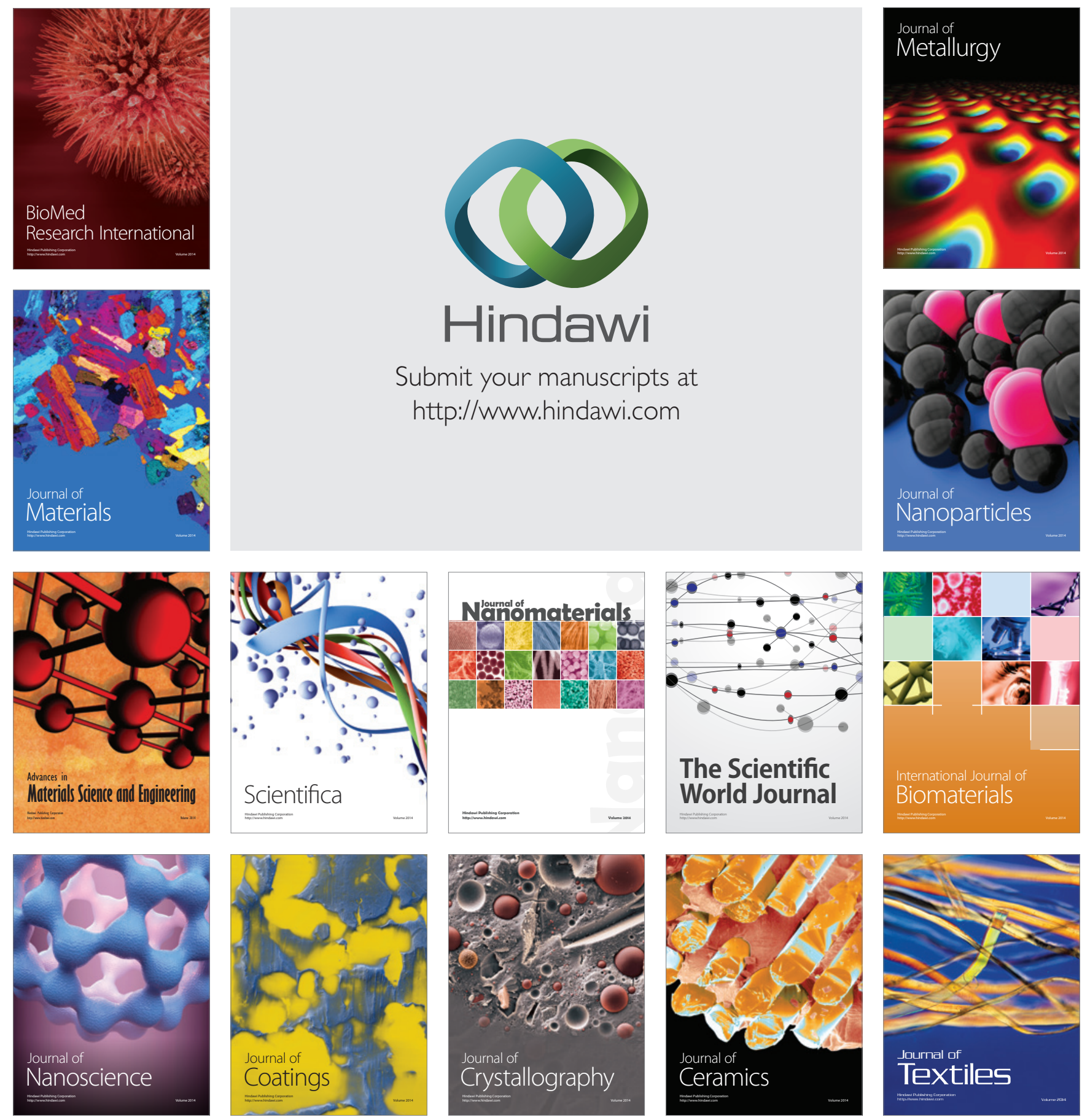